Anna Wszołek

Independent scholar

\title{
Islandzka reforma konstytucyjna w latach 2010-2020
}

Icelandic Constitutional Reform 2010-2020

The Icelandic constitution was passed on June 17, 1944. Amendments were passed in 1959, 1984, 1991,1995 , and, 1999. None of them introduced any significant changes to the original document. The financial crisis of 2008 caused a decline in public trust of politicians and the existing political system in Icelandic society. Icelanders began to demand a review of the constitution. Constitutional reform began in 2010 and continues to this day.

Key words: Iceland, constitution, reform, society, participation

Słowa klucze: Islandia, konstytucja, reforma, społeczeństwo, uczestnictwo.

\section{Początki konstytucjonalizmu w Islandii}

Pierwsza konstytucja dla Islandii została wprowadzona 5 stycznia 1874 roku i była konsekwencją nadania częściowej autonomii przez Danię. Jej zapisy odnosiły się do najważniejszych aspektów funkcjonowania wyspy. Znacząca ich część dotyczyła reformy Althingi, czyli islandzkiego parlamentu ${ }^{1}$, który odtąd miał się składać z dwóch izb: Efri Deild z 12 deputowanymi oraz Netri Deild z 24 (Grzybowski i Pulit 2007: 6). Jeszcze w tym samym roku wprowadzono poprawkę do konstytucji, na mocy której zwiększono skład parlamentu do 40 członków oraz ograniczono uprawnienia duńskiego gubernatora. Kolejne modyfikacje przyjęte w 1904, 1908 oraz 1912 roku wprowadzały zasadę tajności głosowania oraz poszerzały zakres uprawnień Althingi.

\footnotetext{
$1 \quad$ Pierwsze posiedzenie islandzkiego parlamentu odbyło się 1 lipca 1845 r. Początkowo Althingi składał się z 26 członków, z których 20 było wyłanianych w wyborach bezpośrednich, a pozostali otrzymywali nominację z rąk duńskiego króla. Był to kompromis, który miał zaspokoić oczekiwania rodzącego się w Islandii ruchu narodowego.
} 
Dalsze zmiany ustrojowe były związane $\mathrm{z}$ wybuchem I wojny światowej oraz ruchami społecznymi, które przetoczyły się w tym czasie przez Europę. 1 grudnia 1918 roku Islandia zyskała status niepodległego państwa, pozostającego jednak w unii personalnej z Danią. Korona nadal decydowała o kierunkach polityki zagranicznej Islandii, ale w sferze polityki wewnętrznej Islandczycy cieszyli się większą swobodą. Ponownie poszerzono uprawnienia Althingi oraz zwiększono jego skład o 2 osoby na mocy poprawki do konstytucji z 1920 roku (Grzybowski i Pulit 2007: 7).

W kwietniu 1940 roku - w reakcji na zajęcie przez wojska III Rzeszy terytorium Danii - Althingi ogłosił pełną niezależność Islandii, zarówno w sprawach polityki zagranicznej, jak i wewnętrznej. Ta uchwała kończyła okres uzależnienia politycznego Islandii od Korony (Nordal i Kristinsson 1996: 134-135). Ogłoszona wówczas neutralność miała pozwolić Islandii na nieangażowanie się w działania wojenne i skupienie się na organizacji państwa. Zaledwie kilka dni później władze w Londynie podjęły decyzję o ulokowaniu na wyspie żołnierzy w celu zabezpieczenia północnych dróg komunikacyjnych. W 1941 roku zostali oni formalnie zastąpieni przez wojska amerykańskie, które przejęły odpowiedzialność za bezpieczeństwo Islandii na mocy umowy ratyfikowanej przez Althingi.

W 1942 roku przyjęto kolejną poprawkę do konstytucji, tym razem dotyczącą powiększenia składu Althingi o 10 posłów. 17 maja 1943 roku parlament podją1 uchwałę o odmowie przedłużenia unii personalnej z Danią, a o przyszłym ustroju i organizacji państwa miał zdecydować naród $\mathrm{w}$ drodze referendum. W zorganizowanym w dniach 20-23 maja 1944 roku referendum Islandczycy zostali zapytani o następujące kwestie: „Czy zerwać lub nie unię polityczną z Danią? Czy Islandia ma być republiką, czy monarchią?” (Grzybowski i Pulit 2007: 8). Zdecydowana większość (70 536 głosujących) opowiedziała się za zerwaniem unii politycznej oraz republikańską formą rządów (68 862 głosujących) (Grabowski i Grabowska 2008: 173).

Konstytucja Islandii została uchwalona 17 czerwca 1944 roku i stanowi do dziś podstawę prawną funkcjonowania państwa. Kilka razy była nowelizowana, kolejno w 1959, 1984, 1991, 1995 oraz 1999 roku. Pierwsze dwie poprawki dotyczyły zwiększenia liczby deputowanych do Althingi (poszerzono skład z 52 do 60, a następnie z 60 do 63 posłów). W celu „zrównoważonej reprezentacji okręgów wiejskich i stołecznego Reykiaviku" (Grabowski i Grabowska 2008: 174) wprowadzono zmiany w Artykule 33 definiującym kryteria korzystania z czynnego prawa wyborczego. Zniesiono wówczas obowiązek posiadania stałego miejsca zamieszkania na wyspie oraz obniżono cenzus wieku. Nowelizacja z 1991 roku zmieniła organizację parlamentu, likwidując podział na dwie izby. Dwie kolejne poprawki rozszerzyły zapisy dotyczące praw i wolności jednostki, co wynikało ze zobowiązań członkowskich w Radzie Europy.

Konstytucja Islandii składa się z 79 artykułów, z których pierwszy określa Islandię jako republikę „z parlamentarną formą rządów” (Konstytucja Islandii 2009) opartą 
na trójpodziale władzy. Artykuły 3-30 są poświęcone prezydentowi oraz ministrom. Rozwiązania przyjęte $\mathrm{w}$ tej części konstytucji w dużym stopniu są powtórzeniem duńskiej konstytucji z 1849 roku, a zatem rola prezydenta odpowiada roli króla. Kolejne artykuły dotyczą parlamentu (31-58), sądownictwa (59-61), statusu Kościoła Ewangelicko-Augsburskiego oraz wolności religijnej (62-64). Prawom i wolnościom obywatelskim poświęcono artykuły 65-76. Sprawy podatkowe regulują artykuły 77 oraz 78 . Konstytucję zamyka artykuł 79 określający procedurę jej zmiany.

\section{Kryzys finansowy i początek publicznej debaty konstytucyjnej}

Kryzys finansowy z 2008 roku nie tylko wstrząsnął gospodarką Islandii, ale również podważył wiarygodność polityków tworzących wówczas rząd. Utrata płynności przez trzy największe banki (Kaupthing Bank, Landsbankinn, Glitnir Bank) i przejęcie nad nimi kontroli przez Islandzki Bank Centralny, a następnie ogłoszenie bankructwa przez Islandię doprowadziło tego, że z dnia na dzień tracący swoje majątki Islandczycy wyszli na ulicę. Demonstracje objęly cały kraj i przeszły do historii pod nazwą „garnkowej rewolucji”. Z wypowiedzi protestujących przebijał brak zaufania do polityków oraz instytucji publicznych: „Nie ufam rządowi, nie mam zaufania do banków, partii politycznych, MFW. Mieliśmy tu dobry kraj i oni doprowadzili go do ruiny" (Icelanders demand PM resign... 2008, tłum. A.W.). Islandczycy domagali się postawienia przed sądem osób odpowiedzialnych za wybuch kryzysu, co jednak nie było możliwe, ponieważ konstytucja nie określała jasno obowiązków ani zakresu odpowiedzialności poszczególnych organów władzy. Silne poczucie niezależności oraz umiejętność konsolidacji pozwoliły Islandczykom wywierać wpływ na rządzących oraz skutecznie demonstrować sprzeciw wobec obciążania społeczeństwa spłatą zadłużenia prywatnych banków (Banaś 2014: 380-381).

Publiczna dyskusja nad konstytucją rozpoczęła się w 2010 roku i pociągnęła za sobą szereg społecznych inicjatyw mających na celu opracowanie nowej ustawy zasadniczej. 4 listopada 2009 roku premier Jóhanna Sigurðardóttir na posiedzeniu Althingi przedstawiła projekt ustawy o Zgromadzeniu Konstytucyjnym (Frumvarp lagt fyrir á Alpingi...), którego głównym zadaniem było przeprowadzenie przeglądu obowiązującej konstytucji. Zgromadzenie miało się składać co najmniej z 25 i nie więcej niż 31 członków wybranych w wyborach krajowych (Frumvarp til laga...) na okres 9 miesięcy rozpoczynający się nie później niż 17 czerwca 2010 roku i kończący 17 lutego 2011 roku (Frumvarp lagt fyrir á Alpingi...).

Artykuł 3 ustawy określał szczegółowy zakres tematów, nad którymi miało pracować Zgromadzenie Konstytucyjne: „1. Podstawy konstytucji Islandii i podstawowe pojęcia; 2 . Władza ustawodawcza i wykonawcza oraz jej uprawnienia; 3 . Prezydent Republiki; 4. Niezawisłość władzy sądowniczej i nadzór nad innymi osobami sprawującymi władzę państwową; 5. Przepisy dotyczące wyborów i struktury 
okręgów wyborczych; 6. Mechanizmy demokracji bezpośredniej" (Konstytucja Islandii 2009). Obok prezydium planowano powołać trzy komisje robocze: Komisję ds. podstaw islandzkiej konstytucji, sądownictwa i praworządności, Komisję ds. władzy ustawodawczej i wykonawczej oraz roli Prezydenta Republiki oraz Komisję ds. wyborów i referendów. Dodatkowo w 2010 roku powołano specjalną komisję, której zadaniem miało być nadzorowanie prac specjalistów. Postanowiono również, że zostanie zorganizowane specjalne posiedzenie złożone z 1000 obywateli w celu przeprowadzenia szerokich konsultacji.

Pierwszy etap prac nad projektem nowej konstytucji polegał na zebraniu danych dotyczących zagadnień, którymi miało zająć się Zgromadzenie. Planowano, że zostaną one przedstawione 1000 osobom reprezentującym wszystkie grupy społeczne podczas posiedzenia wyznaczonego na 6 listopada 2010 roku ( (jóðfundur 2010). Uczestników wyłoniono drogą losowania spośród osób zarejestrowanych $\mathrm{w}$ krajowych rejestrach partii politycznych. Wypracowane podczas tego spotkania wnioski miały szczególne znaczenie dla dalszych prac. Uzgodniono katalog kluczowych wartości, które powinny stanowić fundament nowej konstytucji. Wśród nich znalazły się „równość, prawa człowieka, demokracja, uczciwość, sprawiedliwość, szacunek, wolność i odpowiedzialność" (bjóðfundur 2010).

Wybory do Zgromadzenia Konstytucyjnego odbyły się 2 grudnia 2010 roku. Frekwencja była niska i wynosiła 35,95\% (Kosningar til stjórnlagapings...). Kilka dni później do Sądu Najwyższego wpłynął wniosek o unieważnienie wyborów. W styczniu 2011 roku sąd wydał wyrok, w którym uznał wybory za nieważne z powodu istotnych uchybień proceduralnych (Ógilding kosninga til stjórnlagapings...).

Unieważnienie wyborów stanowiło spore wyzwanie dla Althingi oraz pani premier. Przeanalizowanie sytuacji oraz opracowanie nowych rozwiązań zlecono więc Radzie Konsultacyjnej, a ta 24 lutego 2011 roku zaproponowała powołanie Rady Konstytucyjnej składającej się z przedstawicieli, którzy otrzymali największą liczbę głosów w wyborach do Zgromadzenia Konstytucyjnego (Skipan pingmannanefndar og störf hennar...). W praktyce Rada miała przejąć funkcję Zgromadzenia Konstytucyjnego, tj. przeanalizować wnioski Komisji Konstytucyjnej oraz opracować i przedstawić projekt zmian konstytucji.

Rezolucja Althingi z 24 marca 2011 roku dała podstawę prawną dla powołania 6 kwietnia 2011 roku Rady Konstytucyjnej, która miała zająć się opracowaniem przejrzystego, jasnego podziału obowiązków i odpowiedzialności między poszczególnymi organami władzy oraz udziałem społeczeństwa w podejmowaniu decyzji (The Constitutional Council hands...).

Rada powołała trzy komisje projektowe do zbadania czternastu zagadnień. Komisja A miała zająć się podstawowymi wartościami, obywatelstwem i językiem narodowym, strukturą konstytucji i podziałem na rozdziały, zasobami naturalnymi i ochroną środowiska, prawami człowieka oraz statusem kościoła państwowego. Komisja B pracowała nad podstawami konstytucji, rolą i zakresem odpowiedzialności prezydenta, parlamentu oraz rządu, obowiązkami władzy wykonawczej oraz 
statusem gmin. Komisji C przydzielono zagadnienia takie jak: procedura zmiany konstytucji, mechanizmy demokracji bezpośredniej, niezawisłość sądów, zakres immunitetu sprawujących władzę i możliwość postawienia ich przed sądem, wybory parlamentarne i system okręgowy oraz umowy międzynarodowe i sprawy zagraniczne (Starfshœettir Stjórnlagaráðs...).

Wspomniane komisje pracowały w poniedziałki i wtorki, a ich propozycje i wnioski były przedstawiane na otwartych posiedzeniach Rady oraz publikowane w mediach społecznościowych. Wszyscy zainteresowani mogli zostawić swój komentarz, który następnie był omawiany przez komisje i przedstawiany Radzie (Áfangaskjal að stjórnarskrá...). Prowadzenie stałych konsultacji ze społeczeństwem i uwzględnianie jego opinii w tworzeniu projektu pozwala twierdzić, że konstytucja Islandii była pisana przez naród, co jest zjawiskiem bez precedensu. Nigdy wcześniej żadne państwo w tak znaczącym stopniu nie włączyło obywateli w proces tworzenia tego typu dokumentu (Fillmore-Patrick 2013: 2).

\section{Projekt nowej konstytucji}

Rada Konstytucyjna przedstawiła parlamentowi projekt nowej konstytucji w lipcu 2011 roku. Dokument składający się ze 114 artykułów otwierała Preambuła. Odwołanie do wspólnych wartości miało zapewnić fundament dla funkcjonowania społeczeństwa, organizacji życia politycznego oraz struktur władzy (Fillmore-Patrick 2013: 3).

Projekt został podzielony na 9 części, które dotyczyły kolejno: podstaw ustroju (artykuły 1-5), praw człowieka i natury (6-36), Althingi (37-75), prezydenta (76-85), ministrów i rządu (86-97), sądownictwa (98-104), samorządów (105-108), spraw zagranicznych (109-112), procedur zmiany konstytucji oraz wejścia jej w życie (113-114). Dokument miał przejrzystą strukturę, co znacznie ułatwiło odnalezienie konkretnych zagadnień.

\subsection{Referendum Konstytucyjne}

Referendum odbyło się 20 października 2012 roku. Spośród 236911 uprawnionych do głosowania głosy ważne oddało 114 570, czyli frekwencja wynosiła 48,99\% (Advertisement of the results of the referendum... 2012). Islandczycy odpowiadali $\mathrm{w}$ referendum na następujące pytania:

1. Czy chcesz, aby podstawą nowego projektu konstytucji były propozycje Rady Konstytucyjnej?

2. Czy chcesz, aby w nowej konstytucji wszelkie zasoby naturalne niemające prywatnego właściciela były uznane za własność narodową?

3. Czy chcesz, aby nowa konstytucja zawierała zapis o ustaleniu kościoła państwowego w Islandii? 
4. Czy chcesz, aby nowa konstytucja umożliwiała wybór konkretnych jednostek do Althingi w większym stopniu niż obecnie?

5. Czy chcesz, aby nowa konstytucja gwarantowała, że głosy oddane w każdej części Islandii będą miały tę samą wagę?

6. Czy chciałbyś, aby nowa konstytucja pozwalała zorganizować referendum na wniosek obywateli? (Advertisement of the results of the referendum... 2012).

Zdecydowana większość głosujących udzieliła twierdzącej odpowiedzi na postawione pytania. Referendum było jednak niewiążące, w związku z tym do dnia dzisiejszego w Islandii obowiązuje konstytucja z 1944 roku.

\subsection{1. Środowisko oraz gospodarka zasobami naturalnymi}

W pytaniu drugim podniesiono kwestię własności. Aktualnie obowiązująca konstytucja w Artykule 72 potwierdza „ochronę nienaruszalności własności prywatnej” (Konstytucja Islandii 2009). Prawo może być ograniczone tylko w sytuacji, gdy wymaga tego „interes publiczny”, a poszkodowanemu przysługuje prawo do pełnego odszkodowania (Konstytucja Islandii 2009). Artykuł ten odnosi się również do możliwości udziału podmiotów zagranicznych w przedsięwzięciach realizowanych na wyspie oraz posiadania przez nie nieruchomości. Także w tym wypadku mamy tu jedynie ogólny zapis i odesłanie do ustawy, która może wprowadzać ograniczenia.

Konstytucja nie odnosi się do gospodarowania zasobami naturalnymi, co zostało dostrzeżone przez Radę Konstytucyjną i zidentyfikowane jako konieczne do zdefiniowania. W 1990 roku Althingi określił zasoby rybne jako „wspólną własność narodu islandzkiego", jednak deklaracja ta nie miała żadnego skutku prawnego (Gylfason 2018).

Zaproponowana Preambuła traktuje dbałość o środowisko naturalne jako wspólny obowiązek Islandczyków (Iceland’s Draft Constitution... 2011). Prawo do korzystania z wolnego dostępu do środowiska naturalnego („zdrowego środowiska, świeżej wody, czystego powietrza" (Iceland's Draft Constitution... 2011) definiuje Artykuł 33. Nakłada on również obowiązek dbania o jego stan oraz poszanowania praw przyrody. Troska o miejsca o znaczeniu przyrodniczym, pomniki przyrody, różnorodność gatunkową roślin i zwierząt, glebę oraz zasoby naturalne zdaniem członków Rady Konstytucyjnej jest zobowiązaniem wobec przyszłych pokoleń.

Artykuł 34 doprecyzowuje, jak należy rozumieć i traktować prawo do korzystania z zasobów naturalnych². Kluczowe wydaje się stwierdzenie, że są one własnością narodu Islandii i nikt nie może ich nabyć, sprzedać czy ustanowić na nich hipoteki (Iceland's Draft Constitution... 2011). Władze państwowe oraz wszyscy ci, którzy

2 Przez zasoby naturalne należy rozumieć: „Ryby nadające się do połowu, inne zasoby mórz i dna morskiego podlegające jurysdykcji islandzkiej oraz źródła wodne i prawa do wykorzystania, prawa do zasobów geotermalnych i górnictwa i prawa do wydobywania. Ponadto w ustawach zwykłych można określić, że zasoby leżące poniżej pewnej głębokości pod powierzchnią gruntu będą stanowiły własność narodową" (Iceland’s Draft Constitution... 2011, tłum. A.W.). 
z tych zasobów naturalnych korzystają, ponoszą odpowiedzialność za zapewnienie im odpowiedniej ochrony. Wszelkie zezwolenia na eksploatację powinny nie tylko być udzielane na niedyskryminacyjnych zasadach i za wynagrodzeniem, ale również $\mathrm{z}$ uwzględnieniem zrównoważonego rozwoju oraz interesu publicznego (Iceland's Draft Constitution... 2011).

Rozwiązania zawarte w projekcie są odpowiedzią na dyskusję toczącą się od lat 60. XX wieku. Już sama definicja „własności państwowej” nastręczała sporo wątpliwości. Problemem było także określenie, jakie elementy zasobów naturalnych mogą być uznane za własność prywatną, a jakie są prawnie z niej wyłączone. Wydaje się, że nazwanie najwyższą wartością „wykorzystania zasobów naturalnych zgodnie z interesem całego narodu, pozwala włączyć do definicji wszystkie rodzaje zasobów naturalnych, niezależnie od tego, czy są one własnością prywatną, państwową czy nie" (Questions on the ballot...).

\subsubsection{Kościół państwowy}

Trzecie pytanie dotyczyło statusu kościoła państwowego. Obecnie obowiązująca konstytucja w Artykule 62 stwierdza: „Kościół Ewangelicko-Augsburski w Islandii jest Kościołem państwowym i jako taki jest wspierany i chroniony przez państwo" (Konstytucja Islandii 2009). Ten stan prawny może zostać zmieniony, jak głosi artykuł 79, w drodze ustawy Althingi, a następnie przedłożony do zatwierdzenia lub odrzucenia „w głosowaniu tajnym przez wszystkich uprawnionych do głosu” (Konstytucja Islandii 2009).

Artykuł 19 projektu konstytucji odnosi się do organizacji kościoła państwowego. Zachowano tu rozwiązania przyjęte już wcześniej - status kościoła państwowego może zostać zmieniony w procedurze dwustopniowej (Iceland's Draft Constitution... 2011). Usunięto natomiast zapis, że to Kościół Ewangelicko-Augsburski posiada status kościoła państwowego. Nie znajdziemy tu także zapisów dotyczących wsparcia ze strony państwa.

Kwestie, do których odnosi się trzecie referendalne pytanie, były przedmiotem żywej dyskusji wśród członków Rady Konstytucyjnej. Podzieliła ona również ekspertów pytanych o rozwiązania, które powinny zostać zaproponowane w projekcie. Dla części z nich usunięcie zapisów dotyczących statusu Kościoła Ewangelicko-Augsburskiego oznaczało w praktyce rozdział kościoła od państwa. W opinii pozostałych kwestia ta powinna zostać poddana pod referendum (Questions on the ballot...).

\subsubsection{Wybór konkretnych jednostek do Althingi}

Pytanie czwarte dotyczyło procedury wyboru przedstawicieli do islandzkiego parlamentu. Zgodnie z Artykułem 31 konstytucji naród wybiera członków Althingi w głosowaniu opartym na zasadzie proporcjonalności, co oznacza, że obywatele 
głosują na partie polityczne, a nie na poszczególnych przedstawicieli tych partii. Szczegółowo ordynację wyborczą określa Artykuł 82 ustawy o ordynacji wyborczej 24/2000 (Lög um kosningar til Albingis). Znajdziemy tam informację, że wyborcy mogą skreślać oraz zmieniać kolejność kandydatów na listach wyborczych. Zabieg ten pozwala częściowo wpływać na wybór konkretnego kandydata, jednak dodatkowe wymagania (m.in. liczba osób, które muszą przekreślić te same nazwiska) ogranicza skuteczność tego rozwiązania. Pewną namiastkę głosowania na konkretnego kandydata stanowią organizowane przez partie polityczne prawybory, które są jednak otwarte tylko dla członków partii oraz ich zwolenników (Questions on the ballot...).

Artykuł 39 projektu odnosi się do zasad wyboru parlamentarzystów. Nie znajdziemy tu zapisu o proporcjonalności. Stowarzyszenia kandydatów (partie) mogą zgłaszać listy zarówno na poziomie okręgowym, jak i krajowym, a sami kandydaci mogą startować jednocześnie z obu tych list (Iceland's Draft Constitution... 2011). Liczba miejsc w parlamencie będzie przydzielana poszczególnym partiom, jednak o wejściu konkretnych kandydatów nie decyduje kolejność zajmowanego miejsca na liście wyborczej, lecz liczba otrzymanych głosów. Rada zaproponowała również, by wyborcy mogli oddawać głosy na konkretnych kandydatów na listach bądź głosować tylko na listę (wówczas o tym, czy dany kandydat wejdzie do Althingi, zdecyduje miejsce, które zajmuje na liście) (Questions on the ballot...).

Zaproponowane tu rozwiązanie służy dwóm kwestiom. Z jednej strony daje większą możliwość wybrania rzeczywiście popieranego kandydata, a z drugiej może wpłynąć na wzrost poczucia odpowiedzialności osób zasiadających w parlamencie (Questions on the ballot...). Ten ostatni aspekt miał szczególne znaczenie dla odbudowy społecznego zaufania do polityków.

\subsubsection{Równość głosów}

Islandczycy zostali również zapytani o zdanie w kwestii uznania równiej wagi głosów, niezależnie od tego, w jakim okręgu wyborczym zostały oddane. Artykuł 31 konstytucji zawiera następujące rozwiązanie: „Jeżeli liczba wyborców umieszczona w spisie wyborców przypadająca na każdy mandat parlamentarny, przyznany lub rozdzielony, osiągnie w jednym z okręgów wyborczych połowę liczby przypadającej na mandat parlamentarny w innym okręgu wyborczym, Państwowa Komisja Wyborcza dokonuje rewizji liczby mandatów przysługujących każdemu okręgowi wyborczemu w celu ograniczenia tych różnic" (Konstytucja Islandii 2009). Nierównowaga nie może być zatem większa niż $1: 2$, a PKW zachowuje prawo do realokacji mandatów w celu utrzymania zakładanej proporcji.

Rada Konstytucyjna w Artykule 39 projektu zawarła zasadę, zgodnie z którą wszystkie oddane głosy (niezależnie od okręgu) mają równą wagę. Nowym rozwiązaniem jest także propozycja przeprowadzenia wyborów bez podziału na okręgi lub przy podziale na nie więcej niż 8 okręgów (Iceland's Draft Constitution... 
2011). W przypadku podziału kraju na okręgi będzie mogło z nich pochodzić tylko 30 parlamentarzystów.

Wprowadzenie równości głosów oraz zniesienie podziału na okręgi wyborcze jest zupełnie nowym rozwiązaniem w Islandii. Nie dziwi zatem fakt, że Rada zdecydowała się na zaproponowanie pośredniego rozwiązania - wybór 33 przedstawicieli w głosowaniu na listy krajowe oraz $30 \mathrm{z}$ list okręgowych.

Wprowadzenie zasady równości głosów jest ważnym krokiem w kierunku zapewnienia większego udziału mieszkańców obszarów o mniejszej gęstości zaludnienia (najczęściej peryferyjnych) w podejmowaniu kluczowych decyzji dla kraju. Dzięki przyjęciu zasady równości głosów mieszkańcy mają szansę na wprowadzenie do Althingi większej liczby swoich przedstawicieli niż w przypadku, gdy o liczbie przedstawicieli decyduje liczebność danego regionu.

\subsubsection{Referendum}

Ostatnie spośród zadanych pytań dotyczyło wymogów formalnych (liczby podpisów zebranych pod wnioskiem o referendum) niezbędnych do rozpisania referendum $\mathrm{z}$ inicjatywy obywateli. Obecnie obowiązująca konstytucja nie przewiduje procedury, która pozwalałaby Islandczykom na złożenie wniosku o przeprowadzenie tego typu głosowania ${ }^{3}$. Ten stan prawny wynika z podejścia charakterystycznego dla krajów nordyckich. Referendum jest traktowane jako mechanizm zachowania równowagi wobec instrumentów demokracji przedstawicielskiej i jako taki jest wykorzystywany tylko w szczególnych okolicznościach (Questions on the ballot...).

W Artykule 65 projektu konstytucji przyjęto rozwiązanie, że już 10\% wszystkich uprawnionych do głosowania może złożyć wniosek o przeprowadzenie referendum, jeśli dotyczy on ustawy przyjętej przez Althingi. Będzie on skuteczny, gdy zostanie złożony nie później niż 3 miesiące od daty przyjęcia ustawy, której dotyczy. Referendum powinno zostać zorganizowane w ciągu roku od złożenia wniosku.

Ważnym krokiem do wzmocnienia mechanizmów demokracji bezpośredniej jest także wprowadzenie obywatelskiej inicjatywy ustawodawczej. Próg w tym przypadku, jak głosi artykuł 66, wynosi 10\% uprawnionych do głosowania (Questions on the ballot...). Obywatelski projekt ustawy jest rozpatrywany przez Althingi. Parlament może również przygotować kontrpropozycję. Jeśli wnioskujący nie wycofają swojego projektu, oba dokumenty zostają poddane ocenie społeczeństwa w drodze referendum ${ }^{4}$. Kluczowa wydaje się decyzja parlamentu, który stwierdza, czy jego wyniki są wiążące, co osłabia moc obywatelskiej inicjatywy ustawodawczej.

Mimo że obecnie konstytucja nie przewiduje procedury, na podstawie której obywatele mogą domagać się przeprowadzenia referendum, istnieją pewne rozwiązania wprowadzone na szczeblu samorządowym.

4 Referendum powinno być zorganizowane w ciągu dwóch lat od daty złożenia projektu obywatelskiego. 
Artykuły 65 i 66 projektu należy interpretować, biorąc pod uwagę ograniczenia, jakie wprowadza Artykuł 67. Zawęża on zakres przedmiotowy referendum oraz obywatelskiej inicjatywy ustawodawczej. Muszą one dotyczyć interesu publicznego i nie mogą odnosić się do ustawy budżetowej lub załączników do niej, wprowadzenia rozwiązań wynikających z przepisów prawa międzynarodowego, kwestii podatkowych i obywatelskich (Iceland's Draft Constitution... 2011). Kwestie sporne (klasyfikacji, czy dana sprawa podlega procedurze opisanej w Artykule 65 i 66) rozstrzyga sąd.

\section{Referendum konstytucyjne i co dalej?}

Mimo że Islandczycy wyrazili swoje poparcie dla przyjęcia projektu konstytucji jako podstawy reformy ustrojowej, nie uzyskał on większości w Althingi. Partie polityczne, a w szczególności Partia Niepodległości wnosiły zastrzeżenia do części z proponowanych rozwiązań.

Wątpliwości wyraziła również Komisja Wenecka poproszona w listopadzie 2012 roku o zaopiniowanie projektu konstytucji. Dotyczyły one stopnia ogólności poszczególnych sformułowań, które mogłyby budzić w przyszłości trudności interpretacyjne (Venice Commission, Opinion No. 702/2013 ... 2013: 3). Podkreślono niejasność oraz brak konsekwencji w definiowaniu systemu instytucjonalnego (określono go jako bardzo złożony, niespójny, niezapewniający równowagi władz) (Venice Commission, Opinion No. 702/2013... 2013: 31), zakresu ochrony praw człowieka (w szczególności praw drugiej i trzeciej generacji), prawa własności, wolności mediów i dostępu opinii publicznej do informacji (Venice Commission, Opinion No. 702/2013... 2013: 7-12). Uwagi dotyczyły również kwestii referendum, które zdaniem komisji wymagały dalszych analiz ${ }^{5}$. Komisja wyraziła obawy co do niejasności zarówno w definiowaniu, w jakich konkretnie okolicznościach ten mechanizm mógłby być użyty, jak i co do procedury przeprowadzenia referendum. Końcowa ocena projektu zawierała obawę, że jego wejście w życie będzie wiązało się pewnym ryzykiem niestabilności politycznej.

Zmiany gabinetów, a wraz z nimi zmieniające się priorytety odsunęly prace nad konstytucją na dalszy plan. Kolejna Komisja Konstytucyjna została powołana na lata 2013-2016 i pracowała nad trzema obszarami: zasoby naturalne, ochrona środowiska oraz referendum. Opracowany przez nią projekt został przedstawiony Althingi w 2016 roku, ale i on nie został przyjęty.

Projekt zakładał szeroki katalog spraw, które mogły podlegać referendum. Począwszy od tych związanych z samorządem terytorialnym (art. 107), przez te dotyczące kwestii legislacyjnych na poziomie krajowym (art. 60, 65-67), usunięcia prezydenta ze stanowiska (art. 84), przeniesienia kompetencji państwowych na organizacje międzynarodowe (art. 111), aż po zmiany konstytucji (art. 113). 
Po wyborach parlamentarnych w 2017 roku formująca się koalicja Ruchu Lewicowo-Zielonych i Partii Niepodległości zobowiązała się do dokończenia reformy ustrojowej. Nie oznaczało to jednak, że projekt złożony w 2011 roku zostanie ponownie poddany pod głosowanie w Althingi.

Plan reformy ustrojowej został podzielony na dwa etapy. W pierwszym etapie obejmującym lata 2018-2021 prace miały się koncentrować na zdefiniowaniu zasad zarządzania zasobami naturalnymi, ochronie środowiska, referendum i inicjatywie obywatelskiej, sprawach międzynarodowych, funkcji prezydenta, władzy wykonawczej oraz procedurach zmian konstytucji (Constitutional Revisions planned for 2018-2025...). Drugi etap, przypadający na lata 2021-2025, będzie poświęcony parlamentowi i jego uprawnieniom budżetowym, statusowi kościoła państwowego, prawom człowieka oraz wszystkim innym nierozstrzygniętym dotąd kwestiom (Constitutional Revisions planned for 2018-2025...). Zakładano, że nad reformą ustrojową będą pracować liderzy wszystkich partii politycznych pod przewodnictwem premiera.

Do dalszych prac nad reformą postanowiono włączyć również społeczeństwo. Instytut Badawczy ds. Nauk Społecznych Uniwersytetu Islandzkiego, któremu zlecono przeprowadzenie badania opinii, ogłosił projekt o nazwie Demokratyczny projekt konstytucji. Sondaż deliberatywny rozpoczął się latem 2019 roku (Finnbogason 2020), a jego wyniki przekazano pani premier w styczniu 2020 roku. Wybraną grupę respondentów pytano o opinię w kwestiach, które miała objąć reforma ustrojowa. 9 i 10 listopada 2019 roku w Reykiaviku odbyło się spotkanie, którego celem było omówienie wyników sondażu. Wzięło w nim udział 233 osób, co stanowi około $10 \%$ spośród wszystkich, których objęto badaniem (Constitutional Revisions planned for 2018-2025...). Prace prowadzono w 27 grupach roboczych, które zajmowały się następującymi kwestiami: prezydent, rola parlamentu w procedurze impeachmentu oraz procedura zmiany konstytucji. Obok tych zagadnień badano również, jakie wartości mają szczególne znaczenie dla respondentów, jak oceniają otoczenie polityczne oraz jaka jest ich aktywność polityczna (Amending the Constitution...).

Pierwszym tematem, który omawiano, była procedura zmiany konstytucji. Opracowano cztery scenariusze: 1 . Zmiana konstytucji zawsze wymaga przeprowadzenia referendum, 2. Zmiana konstytucji wymaga zwykłej większości głosów oddanych przez dwa następujące po sobie składy parlamentarne, 3. Zmiana konstytucji wymaga $5 / 6$ głosów parlamentu oddanych w jednym głosowaniu, 4 . Zmiana konstytucji wymaga $2 / 3$ głosów parlamentu oddanych w jednym głosowaniu. Po pierwszych dyskusjach $82 \%$ pytanych uznało pierwsze z rozwiązań za najbardziej adekwatne. Na uwagę zasługuje również fakt, że $96 \%$ twierdziło, że zmiana ustawy zasadniczej nie powinna być zbyt łatwa do przeprowadzenia. Jednocześnie $71 \%$ pytanych zwróciło uwagę, że konstytucja jest wyrazem potrzeb i oczekiwań społeczeństwa i jako taka powinna móc wraz z nim ewoluować (Amending the Constitution...). Warto również zauważyć, że aż $95 \%$ badanych podkreśliło, że najważniejszą kwestią 
pozostaje dla nich to, aby konstytucja była wyrazem wspólnych dążeń i wartości, bo tylko taka może stanowić trwały fundament.

Dyskutowano również nad powodami, dla których obowiązująca konstytucja powinna zostać zmieniona. Grupa respondentów była w tej kwestii podzielona. Część uważała, że obecna ustawa jest przestarzała, nie odnosi się do obecnej sytuacji i nie służy społeczeństwu. Pozostali uważali, że zawiera ona katalog najważniejszych zasad i spełnia swoją funkcję. Postawienie pytania o to, czy Islandczycy rzeczywiście chcą zmiany konstytucji, a jeśli tak, to w jakim zakresie, jest kluczowe dla zrozumienia powodów, dla których reforma ustrojowa sprzed prawie dziesięciu lat nie zakończyła się sukcesem. Można sądzić, że zakres i tempo prac nad nową konstytucją okazały się zbyt rewolucyjne. Pojawiały się głosy, że tak istotne zmiany powinny być inicjowane stopniowo, „metodą małych kroków” (Amending the Constitution...), tym bardziej, że dotykały one trudnych zagadnień, takich jak na przykład własność zasobów naturalnych.

Niezwykle ważną kwestią była organizacja referendum oraz to, czy wola narodu w nim wyrażona może być ignorowana przez parlament. Omawiano tu sytuację po referendum konstytucyjnym z 2012 roku. Jego wyniki zostały wówczas uznane za doradcze, a nie wiążące, to znacząco osłabiło jego wagę. Warto wspomnieć, że istotnym powodem rozpoczęcia dyskusji nad reformą ustrojową był kryzys zaufania do polityków oraz rozwiązań ustrojowych, które nie dawały jednoznacznej odpowiedzi na pytanie o zakres odpowiedzialności poszczególnych organów władzy. Nie dziwi zatem, że uczestnicy listopadowego spotkania uznali, że parlament nie może ignorować woli narodu, a więc każde referendum powinno mieć charakter wiążący (Amending the Constitution...).

Dyskutowano również o kadencyjności urzędu prezydenta, cenzusie wieku, sposobie wyboru oraz zakresie uprawnień. Poddano analizie procedurę impeachmentu ze szczególnym uwzględnieniem roli parlamentu. Znacząca liczba pytanych (79\%) uznała, że uprawnienie Althingi do wniesienia tego typu sprawy do sądu jest nieuzasadnione i może prowadzić do nadużyć (Summary of conclusions... 2020: 3).

Debatowano także nad wyborami w okręgach, równą wagą wszystkich głosów oraz możliwością głosowania na konkretnego kandydata. Uczestnicy byli zgodni, że głównym celem jest zapewnienie, by wszystkie części kraju miały swoją reprezentację w parlamencie. Rozwiązaniem, które byli skłonni zaakceptować, było podejście hybrydowe, łączące dotychczas obowiązujące "głosowanie na partie polityczne” z „pewnym udziałem” głosowania na konkretnego kandydata (Summary of conclusions... 2020: 3).

Kolejnym tematem była współpraca międzynarodowa oraz delegowanie uprawnień. Zapytano respondentów o to, czy uważają, że zobowiązania wynikające z umów powinny nieść za sobą konieczność zmian konstytucji. Ich zdaniem realizacja postanowień wynikających $\mathrm{z}$ tego typu porozumień powinna być jasno zdefiniowana i nie może być przedmiotem politycznych sporów (Summary of conclusions... 2020: 4). 
W kwestionariuszu znalazły się również pytania o katalog wartości. Pytani mieli wskazać, które w ich opinii są nie tylko cenione, ale i skutecznie wdrożone przez Islandczyków. Podniesienie tego tematu ma szczególne znaczenie, ponieważ za jeden z głównym niedostatków obecnej konstytucji uznano brak odwołania do powszechnie podzielanych wartości.

Po zapoznaniu się z opinią Islandczyków oraz zakończeniu prac nad zagadnieniami z pierwszego bloku 31 lipca 2020 roku premier Katrín Jakobsdóttir zwróciła się z oficjalną prośbą do Komisji Weneckiej o wyrażenie opinii na temat projektów 4 ustaw konstytucyjnych: ustawy o ochronie środowiska, o zasobach naturalnych, referendum, prezydencie, rządzie, funkcjach władzy wykonawczej oraz innych sprawach instytucjonalnych (Venice Commission, Opinion No. 997/2020... 2020).

Komisja wyraziła pozytywną opinię o przedstawionych dokumentach, podkreślając, że proponowane rozwiązania są zgodne z praktyką międzynarodową. Ustawy nie wprowadzają znaczących zmian w zakresie trójpodziału władz, ograniczając się do wprowadzenia kadencyjności urzędu prezydenta, zakresu jego władzy oraz immunitetu. Komisja wyraziła swoje obawy wobec nieprecyzyjności i braku harmonii w przyjętych zapisach. Chodziło głównie o kwestie referendum, definicję „własności narodowej” zasobów naturalnych, wykorzystywania ich z zachowaniem dbałości o zrównoważony rozwój oraz zakresu indywidualnej i zbiorowej odpowiedzialności za stan środowiska naturalnego (Venice Commission, Opinion No. 997/2020... 2020: 28-29).

W 2020 roku temat reformy ustrojowej stał się ponownie częścią społecznej debaty za sprawą grupy aktywistów domagających się przeprowadzenia konsultacji społecznych i uwzględnienia woli narodu w kluczowych dla niego kwestiach (Ćirić 2020). Niezależnie od tych głosów Althingi kontynuuje prace nad reformą ustrojową. Trudno rozstrzygnąć, w jakim stopniu ostateczny projekt zmian będzie uwzględniał rozwiązania przedstawione w 2011 roku.

Przebieg islandzkiej reformy konstytucyjnej udowadnia, że społeczeństwo może mieć realny wpływ na kształtowanie się ustroju państwa. Nie ogranicza się on tylko do wyboru przedstawicieli, ale sięga znacznie dalej (Kinna, Prichard i Swann 2016). Islandczycy definiują wartości, które mają stanowić fundament nowej konstytucji, określają uprawnienia organów władzy, wypowiadają się w kwestiach kościoła państwowego oraz zasobów naturalnych. Mimo że projekt konstytucji opracowany przez naród nie uzyskał wymaganej większości w parlamencie, nie osłabia to jego znaczenia dla reformy konstytucyjnej.

\section{Bibliografia}

Advertisement of the results of the referendum on 20 October 2012. (2012). Stjornarradid, https:// www.stjornarradid.is/efst-a-baugi/frettir/stok-frett/2012/10/31/Advertisement-of-theresults-of-the-referendum-on-20-October-2012/ (dostęp: 15.11.2020).

Áfangaskjal að stjórnarskrá. Stjornarradid, http://www.stjornlagarad.is/starfid/afangaskjal/ (dostęp: 16.11.2020). 
Amending the Constitution. Constitution, https://constitution.hi.is/deliberative-poll/amending-the-constitution/ (dostęp: 17.11.2020).

Banaś, M. (2014). Alegorie współczesnej Europy - Kryzys finansowy „2008+” dla państwa dobrobytu. Przypadek nordycki. W: P. Borowiec, R. Kłosowicz i P. Ścigaj (red.). Odmiany współczesnej nauki o polityce. T. 2. Kraków: Wydawnictwo Uniwersytetu Jagiellońskiego.

Constitutional Revisions planned for 2018-2025. Constitution, https://constitution.hi.is/resources/ constitutional-revision-in-iceland/icelandic-constitutional-revision-2018-2025/ (dostęp: 17.11.2020).

Ćirić, J. (2020). In Focus: Where is Iceland's Updated Constitution? Iceland Review, https://www. icelandreview.com/politics/in-focus-where-is-icelands-updated-constitution/ (dostęp: 16.11.2020).

Fillmore-Patrick, H. (2013). The Iceland Experiment (2009-2013): A Participatory Approach to Constitutional Reform. Democratization Policy, http://www.democratizationpolicy.org/pdf/ dpc\%20policy\%20note\%202_\%20the\%20iceland\%20experiment.pdf (dostęp: 31.10.2020).

Finnbogason, S. (2020). Results from the Deliberative Poll on the Icelandic Constitution. Constitution, https://constitution.hi.is/results-from-the-deliberative-poll-on-the-icelandic-constitution/ (dostęp: 17.11.2020).

Frumvarp lagt fyrir á Alpingi. Stjornlagarad, http://www.stjornlagarad.is/upplysingar/um-stjornlagarad/ (dostęp: 16.11.2020).

Frumvarp til laga um stjórnlagaping (Lagt fyrir Alpingi á 138. löggjafarpingi 2009-2010). Althingi, https://www.althingi.is/altext/138/s/0168.html (dostęp: 16.11.2020).

Grabowski, R. i S. Grabowska. (2008). Zasady zmiany konstytucji w państwach europejskich. Warszawa:. Wolters Kluwer Business.

Grzybowski, M. i A. Pulit. (2007). Althing Parlament Islandii. Warszawa: Wydawnictwo Sejmowe.

Gylfason, T. (2018). Iceland's Ongoing Constitutional Fight. Verfassungsblog, https://verfassungsblog.de/icelands-ongoing-constitutional-fight/ (dostęp: 28.03.2021).

Icelanders demand PM resign during violent protests. France24, 23. listopada 2008. http:// www.france24.com/en/20081123-protests-geir-haarde-resignation-financial-crisis-iceland (dostęp: 11.08.2011).

Iceland's Draft Constitution of 2011. Draft of 29 Jul 2011. Constitute Project, https://www. constituteproject.org/constitution/Iceland_2011D.pdf?lang=en (dostęp: 15.11.2020).

Kinna R., A. Prichard i T. Swann. (2016). Iceland's crowd-sourced constitution: hope for disillusioned voters everywhere. The Conversation, https://theconversation.com/icelands-crowd-sourced-constitution-hope-for-disillusioned-voters-everywhere-67803 (dostęp: 29.03.2021).

Konstytucja Islandii. (2009). Tłum. J. Osiński. Warszawa: Wydawnictwo Sejmowe.

Kosningar til stjórnlagapings. Stjornlagarad, http://www.stjornlagarad.is/upplysingar/um-stjornlagarad/ (dostęp: 16.11.2020).

Lög um kosningar til Alpingis. Althingi, https://www.althingi.is/lagas/nuna/2000024.html (dostęp:15.11.2020).

Nordal J. i V. Kristinsson. (1996). The Republic Iceland. Reykjavik: The Central Bank of Iceland.

Ógilding kosninga til stjórnlagapings. Stjornlagarad, http://www.stjornlagarad.is/upplysingar/ um-stjornlagarad/ (dostęp: 16.11.2020).

Questions on the ballot - discussion and clarification. Thjodaratkvaedi, http://www.thjodaratkvaedi.is/2012/en/question_on_the_ballot.html (dostęp: 15.11.2020).

Skipan pingmannanefndar og störfhennar. Stjornlagarad, http://www.stjornlagarad.is/upplysingar/um-stjornlagarad/ (dostęp: 16.11.2020).

Starfshœettir Stjórnlagaráðs. Stjornlagarad, http://www.stjornlagarad.is/upplysingar/um-stjornlagarad/ (dostęp: 16.11.2020). 
Summary of conclusions of the deliberative poll - public consultation on revision of The Constitutional Council hands over the bill for a new constitution. (2020). Stjornlagarad http://www. stjornlagarad.is/english/ (dostęp: 16.11.2020).

The Icelandic Constitution. Felagsvisindastofnun-verkefni, s. 2, https://felagsvisindastofnun-verkefni.hi.is/wp-content/uploads/2020/01/Loka_Samantekt-ni\%c3\%b0ursta\%c3\%b0na-R\%c3\%b6kr\%c3\%a6\%c3\%b0uk\%c3\%b6nnunar_ens.pdf (dostęp: 17.11.2020).

Venice Commission, Opinion No. 702/2013. CDL-AD(2013)010. (2013). s. 3, https://www.venice. coe.int/webforms/documents/?pdf=CDL-AD(2013)010-e (dostęp: 15.11.2020).

Venice Commission, Opinion No. 997/2020. CDL-AD(2020)020. (2020), https://www.venice.coe. $\mathrm{int} /$ webforms/documents/?country=60\&year=all (dostęp: 15.11.2020).

pjóðfundur. (2010). Stjornlagarad, http://www.stjornlagarad.is/upplysingar/um-stjornlagarad/ (dostęp: 16.11.2020). 